\title{
Calanipeda aquaedulcis and Arctodiaptomus salinus are exceptionally euryhaline osmoconformers: evidence from mortality, oxygen consumption, and mass density patterns
}

\author{
Leonid Svetlichny*, Elena Hubareva, Antonina Khanaychenko \\ Institute of Biology of the Southern Seas, Sevastopol 99011, Ukraine
}

\begin{abstract}
Mortality, respiration rate, and body mass density of the estuarine copepods Calanipeda aquaedulcis and Arctodiaptomus salinus and their eggs were studied over a wide range of salinities. Empirical hydrodynamic modeling was applied to calculate body mass density using the sinking speed of the copepods. According to the index of median lethal salinity $\left(\mathrm{LS}_{50}\right)$, the salinity tolerance ranges of $C$. aquaedulcis and A. salinus reared at 18 psu were 0.1 to 50 and 0.1 to 35 psu, respectively. No significant effect of salinity on the specific oxygen consumption rate was found in the range from 0.1 to $40 \mathrm{psu}$ in both species, while mean body mass density increased iso-osmotically with water salinity from (mean $\pm \mathrm{SD}$ ) $1.053 \pm 0.007$ to $1.077 \pm 0.005 \mathrm{~g} \mathrm{~cm}^{-3}$ in C. aquaedulcis and from $1.039 \pm 0.004$ to $1.062 \pm 0.007 \mathrm{~g} \mathrm{~cm}^{-3}$ in A. salinus. However, body density contrast and sinking speed were stable in both species, allowing them to avoid buoyancy problems with changing salinity. The mean mass density of resting eggs in A. salinus gradually increased isoosmotically following gradual changes in salinity. In contrast to resting eggs, the mass density of subitaneous eggs was not altered by changes in the surrounding salinity, suggesting a hysteresis response in these eggs.
\end{abstract}

KEY WORDS: Calanipeda aquaedulcis $\cdot$ Arctodiaptomus salinus $\cdot$ Salinity tolerance $\cdot$ Respiration rate $\cdot$ Body mass density

\section{INTRODUCTION}

Calanipeda aquaedulcis Kritschagin, 1873 and Arctodiaptomus salinus Daday, 1885 are typical representatives of holoplanktonic calanoid copepods abundant in estuaries and shallow coastal marine waters. Ephemeral and semi-permanent estuarine and coastal ecosystems are strongly affected by local environmental events (rain, evaporation, river flow, tides), resulting in frequent and unpredictable salinity changes (Ganning 1971, Ranta 1982, Devreker et al. 2008). To survive in fluctuating environments, copepods require behavioural and physiological adaptations.
Copepods in oceanic and coastal waters are known to be principally osmoconformers (Mauchline 1998), i.e. their body fluids are isotonic to the external medium. In osmoconformers, changes in environmental salinity lead to changes in internal osmolarity (Lance 1965), body density (McAllen et al. 1998, Knutsen et al. 2001), and behavior (Seuront 2006).

Some copepods may possess homeostatic mechanisms which permit physiological compensatory osmoregulation. Osmoregulatory responses to salinity alterations in organic osmolyte content are found in the marine copepod Eurytemora affinis (Roddie et al. 1984) and estuarine copepods Tigriopus californicus (Goolish \& Burton 1989) and Temora longicornis 
(Tang et al. 2000). The ability to regulate the inorganic ion content of hemolymph is found in the benthic copepod Tisbe reticulata (Battaglia \& Bryan 1964) and pelagic copepods Calanoides acutus and Rhincalanus gigas (Sartoris et al. 2010). However, the maintenance of ionic content and body density associated with a decrease in salinity and density of surrounding fluid would pose problems for females of species that carry eggs in an ovisac. The mass density may directly influence the ability of adults and their eggs to maintain a vertical position in favorable water layers.

Due to their ubiquitous distribution in brackish, marine, and hyper-saline environments, Calanipeda aquaedulcis and Arctodiaptomus salinus are appropriate candidate species to investigate the mechanisms allowing copepods to compensate for salinity stress. Little is known about the salinity tolerance and capacity for osmoregulation in these species. The objective of this study was to investigate the effects of gradual salinity changes on (1) mortality of C. aquaedulcis and A. salinus, in order to estimate the salinity tolerance range; and (2) respiration rate, body and egg mass density, and density contrast, in order to evaluate the ability of these copepods to osmoregulate across a wide range of salinities.

\section{MATERIALS AND METHODS}

\section{Experimental set-up and effect of salinity variation on mortality}

The experiments were conducted on adult females and males of Calanipeda aquaedulcis and Arctodiaptomus salinus from cultures. These copepod species have been in culture at the Institute of Biology of the Southern Seas (Sevastopol) since 2007. The cultures were originally generated from individuals collected from salt lakes (located near the Black Sea coast of the Kerch peninsula, Crimea), and are continuously cultivated in $0.45 \mu \mathrm{m}$ filtered Black Sea water (FSW) of $18 \mathrm{psu}$ at room temperature $\left(20-22^{\circ} \mathrm{C}\right)$ and fed ad libitum a mixture of the microalgae Isochrysis galbana, Prorocentrum minimum, and P. micans.

Laboratory studies of the effects of salinity on mortality, copepod body and egg mass density and oxygen consumption of both species were conducted from spring 2010 to spring 2011. To estimate the salinity tolerance range (for survival), 20 to 30 actively moving individuals of Calanipeda aquaedulcis or Arctodiaptomus salinus were placed in $100 \mathrm{ml}$ beakers (1 gender and species per beaker in 3 to 5 replicates) containing FSW (18 psu) and then subjected to a gradual salinity decrease or increase over periods ranging from 6 to $8 \mathrm{~h}$, which conformed to the duration of tidal cycles in estuaries of the Mediterranean region (Roddie et al. 1984, Devreker et al. 2008) and the time needed for the regulation of organic osmolyte concentration, body volume and oxygen consumption following osmotic stress in copepods (Goolish \& Burton 1989).

To study the effect of salinity changes on copepod mortality, 3 treatments were used:

(1) Salinity was gradually increased at a rate of about 3 psu h ${ }^{-1}$ over 6 and $8 \mathrm{~h}$, from 18 to 35 and $40 \mathrm{psu}$ for Arctodiaptomus salinus and Calanipeda aquaedulcis, respectively. A further increase in salinity at the same rate led to a pronounced decrease in locomotor activity; therefore, the copepods were acclimated at these salinities for $5 \mathrm{~d}$ before further increasing the salinity above 35 and $40 \mathrm{psu}$. After that, only actively swimming and feeding individuals were exposed to further increases in salinity at a rate of 3 to $4 \mathrm{psu} \mathrm{h}^{-1}$ up to two different final salinities of 50 and 60 psu in Calanipeda aquaedulcis, and up to 40 and $70 \mathrm{psu}$ in Arctodiaptomus salinus.

(2) Salinity was gradually decreased over $6 \mathrm{~h}$ from 18 to 1 psu at a rate of about $3 \mathrm{psu} \mathrm{h}^{-1}$. Preliminary experiments revealed that a decrease in salinity from 18 to 0.2 psu in $1 \mathrm{~d}$ resulted in the loss of the majority of the Calanipeda aquaedulcis specimens due to body swelling; they were therefore kept for about $20 \mathrm{~h}$ at $1 \mathrm{psu}$. Salinity was then gradually decreased further to $0.1-0.2$ psu during $5 \mathrm{~h}$ at a rate of about $0.2 \mathrm{psu} \mathrm{h}^{-1}$.

(3) After long-term (up to $3 \mathrm{mo}$ ) maintenance in fresh water $(0.2 \mathrm{psu})$, copepods were gradually acclimated to $6,14,18,22,30$ and 40 psu over 6 to $8 \mathrm{~h}$ at a rate of 1 to $5 \mathrm{psu} \mathrm{h}^{-1}$.

During all experiments, the copepods experienced the gradual salinity alteration by being transferred every hour to the next salinity increment. Three to 5 replicates were used for each salinity treatment in both species. Low- and high-salinity waters were prepared by stepwise addition (and steady interfusion) of distilled water or artificial sea salt to FSW of $18 \mathrm{psu}$. Water salinity ( $S$, psu) was measured by a Hach conductivity meter (SensIon 5). Throughout the periods of acclimation to low or high salinity, the copepods were fed with the microalga Haemotococcus pluvialis or a mixture of the microalgae Dunaliella tertiolecta, Monochrysis lutheri, and Prorocentrum micans, respectively. 
The number of live (actively swimming and containing food in the guts) and dead individuals was counted during the gradual salinity changes and after the salinity changes during long-term maintenance in water of increased or decreased salinity ( 5 to $10 \mathrm{~d}$ of maintenance at the final salinity). Copepod mortality $(M, \%)$ was calculated as: $M=100 \mathrm{D} /$ $(D+s)$, where $D$ is the number of dead individuals, and $s$ is the number of surviving individuals. The salinity tolerance range in Calanipeda aquaedulcis and Arctodiaptomus salinus was estimated taking into account the lethal salinity values affecting $50 \%$ of the original number $\left(\mathrm{LS}_{50}\right)$ (Hopper 1960, Parra et al. 2005, Chen et al. 2006) in 5 to $10 \mathrm{~d}$. We chose this period because the process of salinity acclimation in crustaceans usually takes at least 3 d (Lance 1963, Khlebovich 1981, Lee \& Petersen 2003).

\section{Oxygen consumption rate}

Actively swimming adult females and males of each species ( $n=200-300)$ were separated from the culture kept at 18 psu and divided into 2 groups, using a wide-mouth pipette. One group underwent a gradual salinity decrease from 18 to $0.1-0.2 \mathrm{psu}$ (as in Treatment 2), while the other group experienced a gradual salinity increase from 18 to about 40 psu (as in Treatment 1). Thereafter, both groups were kept at the final salinities for $1 \mathrm{wk}$ and fed ad libitum. Prior to the experiments, the copepods were placed into $100 \mathrm{ml}$ beakers containing filtered (mesh size of $0.45 \mu \mathrm{m})$ FSW and deprived of food for approximately $2 \mathrm{~h}$ to allow emptying of the guts. Oxygen consumption rate was measured separately for each gender and species.

Respiration rate $\left(R, \mu g \mathrm{O}_{2}\right.$ ind $\left.^{-1} \mathrm{~h}^{-1}\right)$ was determined using the closed sealed chamber method, with experimental and control syringes of $2.0 \mathrm{ml}$ used as the respirometers. Three to 5 females or 6 to 8 males (to equalize copepod weight per volume of respirometers because females are heavier than males) of Calanipeda aquaedulcis and Arctodiaptomus salinus per $1 \mathrm{ml}$ of FSW were gently transferred by a pipette into the experimental syringe, which was filled with FSW supplied through a protective sieve disc (mesh size $200 \mu \mathrm{m}$ ) at the confluent outlet.

To obtain identical oxygen, salinity, and seston content, we connected the control and experimental syringes with a plastic tube and pumped the water through it back and forth several times. The syringes were then separated, closed by stoppers, and placed into a dark chamber at $20 \pm 0.5^{\circ} \mathrm{C}$. The incubation period was ca. $2 \mathrm{~h}$ for Arctodiaptomus salinus and $3 \mathrm{~h}$ for Calanipeda aquaedulcis. At the end of the exposure, a water sample from the experimental or control syringes was transferred to a flow chamber with a variable volume (up to $0.3 \mathrm{ml}$ ) created from a truncated all-glass syringe and joined to a luminescent dissolved oxygen sensor (Hach LDO ${ }^{\mathrm{TM}}$ ). Details concerning the oxygen concentration and respiration rate measurements are described in Svetlichny \& Hubareva (2005) and Svetlichny et al. (2010).

\section{Body size, volume and wet weight}

The total length $\left(L_{\mathrm{tot}}, \mathrm{mm}\right)$ and length and width of the prosome ( $l_{\mathrm{pr}}$ and $\left.d_{\mathrm{pr}}, \mathrm{mm}\right)$ of Calanipeda aquaedulcis and Arctodiaptomus salinus were measured under a light microscope fitted with an eyepiece micrometer. Body volume $\left(V_{\mathrm{b}}, \mathrm{mm}^{3}\right)$ was calculated using the equation $V_{\mathrm{b}}=0.47 L_{\mathrm{tot}}{ }^{0.21} l_{\mathrm{pr}}{ }^{0.93} d_{\mathrm{pr}}{ }^{1.86}$. This equation was based on the empirical relationship between wet weight and body proportions determined in 80 Copepoda species (Svetlichny 1983a) and approximated to the cubic equation $V_{\mathrm{b}}=k L_{\text {tot }}{ }^{3}$, where $k$ is the volume/size coefficient expressed in the present study by the function $k \sim f\left[l_{\mathrm{pr}} / L_{\mathrm{tot}}\left(d_{\mathrm{pr}} / L_{\mathrm{tot}}\right)^{2}\right]$ as $k=0.47\left(l_{\mathrm{pr}} d_{\mathrm{pr}}^{2} / L_{\mathrm{tot}}{ }^{3}\right)^{0.93}$ for both females and males of calanoid and cyclopoid copepods (see Fig. S1 in the supplement at www.int-res.com/articles/suppl/ m470p015_supp.pdf) with body shapes varying from spherical (e.g. Pachos punctatum) to elongated ellipsoid (e.g. Rhincalanus nasutus). Wet weight (WW, mg) was calculated as WW $=V_{b} \rho_{b}$, where $\rho_{b}\left(\mathrm{mg} \mathrm{mm}^{-3}\right)$ is the mean body mass density.

\section{Copepod sinking speed and body mass density}

Sinking speed and body mass density were measured at $22 \pm 0.5^{\circ} \mathrm{C}$ in females of Calanipeda aquaedulcis and Arctodiaptomus salinus from the culture kept at 18 psu: (1) after gradual salinity decrease to 1-2 psu (Day 1) and 0.2-0.3 psu (Day 2) and (2) after gradual salinity increase to $30 \mathrm{psu}$ (Day 1) and 40 psu (Day 2). Sinking speed and mass density of copepods were also measured at the final salinities at the end of $1 \mathrm{wk}$. At least 15 individuals of each species and gender were studied at each salinity. The effect of $8 \mathrm{~d}$ of starvation on mass density of C. aquaedulcis (the more susceptible species to food limitation in comparison with $A$. salinus) was studied at $18 \mathrm{psu}$. 
To determine sinking speed, individuals were anesthetized with 1:5000 MS-222 Sandoz until complete immobilization was achieved (not more than $2 \mathrm{~min}$ ) and were transferred into a $30 \mathrm{~cm}$ long, vertically oriented graduated tube $(\varnothing: 2 \mathrm{~cm})$ filled with seawater of the given density and temperature (described in the previous paragraph). When introduced into the tube, the animals always assumed one of their typical geometric positions: when the antennules were spread, the long axis of the body was horizontal or vertical (with the abdomen down), and when the antennules were folded along the body, the long axis was vertical (with the head down).

To minimize the effect of water thermal convection, the tube was completely submerged in a cylinder $(\varnothing: 5 \mathrm{~cm})$ with circulating water of a constant temperature $\left(21.5\right.$ to $\left.22.5^{\circ} \mathrm{C}\right)$. The sinking speed of each individual was calculated as the mean (of 10 replicates) time of sinking $20 \mathrm{~cm}$ down the tube, observed through a binocular microscope focused on the central axis of the tube. Previous studies (e.g. Stepanov \& Svetlichny 1981) have shown that the wall of a vessel affects the sinking speed of copepods only if the animals are located near the wall (closer than 10 body lengths). Therefore, we did not take into consideration the result of the experiment when the distance between the copepod body (diameter of ca. 0.25 to $0.45 \mathrm{~mm}$ ) and the wall of the vessel was $<5 \mathrm{~mm}$.

Body mass density was determined by $\rho_{\mathrm{b}}=\rho_{\mathrm{w}}(1+$ $\left.C_{\mathrm{D}} S U^{2} / 2 g V_{\mathrm{b}}\right)$, where $\rho_{\mathrm{w}}$ is the water density $\left(\mathrm{g} \mathrm{cm}^{-3}\right) ; S$ is the body cross-sectional area $\left(\mathrm{cm}^{2}\right)$; $U$ is the sinking speed $\left(\mathrm{cm} \mathrm{s}^{-1}\right) ; g$ is the acceleration due to the gravity $\left(\mathrm{cm} \mathrm{s}^{-2}\right)$; and $C_{D}$ is the hydrodynamic drag coefficient. $S$ was expressed as $S=$ $\pi d_{\mathrm{pr}}{ }^{2} / 4$, and $C_{\mathrm{D}}$ was determined as $C_{\mathrm{D}}=c / \mathrm{Re}^{n}$, where Re is the Reynolds number, $n$ is the regression slope, and $C$ is the hydrodynamic shape factor. Taking into account that $\operatorname{Re}=d_{\mathrm{pr}} U / v$, where $v$ is the kinematic molecular viscosity $\left(\mathrm{cm}^{2} \mathrm{~s}^{-1}\right), C_{\mathrm{D}}$ can be calculated as $C_{\mathrm{D}}=c v^{n} / d_{\mathrm{pr}}{ }^{n} U^{n}$. Finally, the equation for calculation of body mass density in copepods can be expressed as $\rho_{\mathrm{b}}=\rho_{\mathrm{w}}\left(1+c \pi v^{n} d_{\mathrm{pr}}^{2-n} U^{2-n} / 8 g V_{\mathrm{b}}\right)$.

To determine the hydrodynamic coefficients $C$ and $n$, previous data on the hydrodynamic characteristics of passive sinking for 16 copepod species (Svetlichny 1983b) were recalculated (see Table S1 in the supplement). Three types of copepod body orientation during sinking were studied: sinking with the head down and the antennules folded along the body $\left(\mathrm{O}_{\mathrm{I}}\right)$, sinking with the abdomen down and antennules spread at an angle of $90^{\circ}$ to the body axis $\left(\mathrm{O}_{\text {II }}\right)$, and sinking dorsally in a horizontal position with spread antennules $\left(\mathrm{O}_{\text {III }}\right)$. When $\mathrm{Re}<1.0, n=1.0$ in every type of body orientation, and when $1.0<\operatorname{Re}<10.0, n=$ 0.87 both for $\mathrm{O}_{\text {I }}$ and $\mathrm{O}_{\text {II }}$ and 0.82 for $\mathrm{O}_{\text {III }}$.

The coefficient $c$ was expressed as a function of the ratio $l_{\mathrm{an}} l_{\mathrm{pr}}: d_{\mathrm{pr}}^{2}$, where $l_{\mathrm{an}}$ is the length of 1 antenna. We found that for orientation $\mathrm{O}_{\mathrm{I}}, C=2.27 l_{\mathrm{an}} l_{\mathrm{pr}} / d_{\mathrm{pr}}{ }^{2}+$ 52.8; $\mathrm{O}_{\mathrm{II}}, C=5.1 l_{\mathrm{an}} l_{\mathrm{pr}} / d_{\mathrm{pr}}^{2}+70.9$; and $\mathrm{O}_{\mathrm{III}}, C=6.17 l_{\mathrm{an}}$ $l_{\mathrm{pr}} / d_{\mathrm{pr}}{ }^{2}+72.4$ (Fig. S2 in the supplement).

The density of seawater was calculated taking into account the temperature (measured with an accuracy of $\pm 0.1^{\circ} \mathrm{C}$ ) and salinity (determined by a conductivity probe SensIon 5, accuracy of $\pm 0.1 \mathrm{psu}$ ) using Oceanological Calculator 2.1 (V. S. Arkhipkin).

\section{Egg sinking speed and mass density}

All measurements of egg sinking speed and mass density were performed at $22 \pm 0.5^{\circ} \mathrm{C}$. Subitaneous eggs of Calanipeda aquaedulcis were collected from females cultivated at a constant salinity of $18 \mathrm{psu}$. In addition, subitaneous and resting eggs (colored grey just after laying and changing to pink color after several weeks of cold storage) were obtained from 2 groups of Arctodiaptomus salinus females kept in fresh (0.2 psu) and brackish (18.2 psu) water. Sinking speed and density were measured in the eggs of $A$. salinus after gradual salinity increase or decrease during $6 \mathrm{~h}$ in the range of 0.2 to $18.2 \mathrm{psu}$ at a rate of 2 to $3 \mathrm{psu} \mathrm{h}^{-1}$. The ovisacs were carefully separated from anesthetized females via dissecting needle, and the eggs were surgically removed from the ovisac and washed in filtered water of the experimental salinity. Eggs $(\mathrm{n}=1-3)$ from each ovisac (not less than 10 ovisacs were used) were transported separately by a thin dropper to the measuring tube. The measurements of egg sinking speed were carried out using the same method as that for sinking adult females (see 'Materials and methods; Copepod sinking speed and body mass density') but with a measuring tube of a smaller diameter $(0.8 \mathrm{~cm})$.

The eggs of the studied species were spherical, and the Reynolds number during their sinking was low (maximum values of Re were 0.04 and 0.08 for Calanipeda aquaedulcis and Arctodiaptomus salinus, respectively). Consequently, the mass density of these copepod eggs $\left(\rho_{\text {egg }}, \mathrm{g} \mathrm{cm}^{-3}\right.$ ) was determined from sinking speed following the Stokes equation (Happel \& Brenner 1965): $\rho_{\text {egg }}=\left(3 v \pi d_{\text {egg }} U+\rho_{\mathrm{w}} g V_{\text {egg }}\right) /$ $g V_{\text {egg }}$, where $d_{\text {egg }}$ is the egg diameter measured under a compound microscope at $400 \times$. Egg volume was calculated as $V_{\text {egg }}=\pi d_{\text {egg }}{ }^{3} / 6$. 


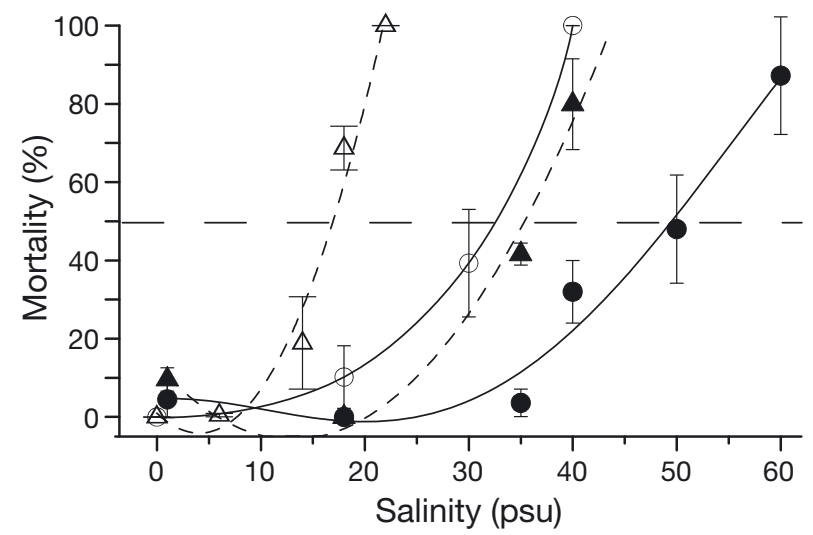

Fig. 1. Arctodiaptomus salinus and Calanipeda aquaedulcis. Salinity tolerance ranges of $A$. salinus (short-dashed lines) reared at $0.1(\Delta)$ and $18(\mathbf{\Delta})$ psu and $C$. aquaedulcis (solid lines) reared at $0.1(\mathrm{O})$ and $18(\mathbf{O}) \mathrm{psu}$. The salinity tolerance range in females and males of both species was between $0.1 \mathrm{psu}$ and the points denoting $50 \%$ mortality (horizontal long-dashed line) after $5 \mathrm{~d}$ of exposure to a given salinity. Solid and short-dashed lines are the polynomial regression curves. Values are means $\pm \mathrm{SD}$

\section{Statistical analyses}

Statistical evaluation of data was conducted by 1-way analysis of variance and Student's $t$-test. Values presented in the figures and tables are means $\pm \mathrm{SD}$.

\section{RESULTS}

\section{Long-term tolerance after gradual salinity changes}

Mortality of males and females of Calanipeda aquaedulcis reared at $18 \mathrm{psu}$ did not exceed $5 \%$ during $10 \mathrm{~d}$ after gradual salinity decrease or increase in the range of 0.2 to $35 \mathrm{psu}$, whereas after the gradual salinity increase from 18 to 40 psu and the subsequent increase to $50 \mathrm{psu}$ (after $5 \mathrm{~d}$ exposure at $40 \mathrm{psu})$, mortality significantly ( $\mathrm{p}<0.001)$ increased to $32 \pm 8$ and $48 \pm 14 \%$, respectively (Fig. 1 ). Of the C. aquaedulcis individuals preliminarily acclimated over $5 \mathrm{~d}$ to $35 \mathrm{psu}, 87 \pm 15 \%$ died during the $10 \mathrm{~d}$ ( 5 days of acclimation to $35 \mathrm{psu}+5$ days of acclimation to final salinity) following the salinity increase to $60 \mathrm{psu}$.

After 2 months of acclimation to fresh water (0.2 psu), $10 \pm 8 \%$ of Calanipeda aquaedulcis that had been subjected to a gradual salinity increase from 0.2 to $18 \mathrm{psu}$ at a rate of $4 \mathrm{psu} \mathrm{h}^{-1}$ died during the $10 \mathrm{~d}$ exposure at final salinity. After a salinity increase from 0.2 to $30 \mathrm{psu}$ at the same rate, $39 \pm 13 \%$ of $C$. aquaedulcis died during the $8 \mathrm{~d}$ exposure, whilst an increase in salinity from 0.2 to $40 \mathrm{psu}$ at a rate of $5 \mathrm{psu} \mathrm{h}^{-1}$ resulted in $100 \%$ mortality on Day 1 of the exposure experiment.

In the experiment with the gradual salinity decrease from 18 to $0.2 \mathrm{psu}$, the mortality of Arctodiaptomus salinus was $10 \pm 3 \%$ after $10 \mathrm{~d}$ of maintenance at the final salinity. We observed sharp increases in mortality, up to $42 \pm 3$ and $80 \pm 15 \%$, after gradual (over $8 \mathrm{~h}$ ) salinity increases from 18 to $35 \mathrm{psu}$ and from 18 to $40 \mathrm{psu}$, respectively, during 5 to $10 \mathrm{~d}$ of maintenance at the final salinities. Few individuals of A. salinus acclimated to $40 \mathrm{psu}$ during $10 \mathrm{~d}$ survived in the hyper-saline water of 70 psu (not shown in Fig. 1).

In Arctodiaptomus salinus cultivated in fresh water ( $0.2 \mathrm{psu}$ ) for $3 \mathrm{mo}$, mortality was $18.9 \pm 12 \%$ after a gradual salinity increase from 0.2 to $14 \mathrm{psu}$ at a rate of $2 \mathrm{psu} \mathrm{h}^{-1}$, whereas after a gradual salinity increase from 0.2 to $18 \mathrm{psu}$ at the same rate, the mortality of this group reached $69 \pm 6 \%$. None of the copepods survived an abrupt salinity increase from 0.2 to 22 psu during $8 \mathrm{~h}$. No egg production was observed in A. salinus and Calanipeda aquaedulcis kept at salinities higher than 40 and 50 psu, respectively. Moreover, nauplii did not hatch from the eggs of females transferred to hyper-saline water with the ovisacs.

\section{Effect of salinity on adult respiration rate}

While at 39.2 psu the respiration rate of female Arctodiaptomus salinus $\left(0.131 \pm 0.018 \mu \mathrm{g} \mathrm{O} \mathrm{O}_{2}\right.$ ind. $^{-1}$ $\mathrm{h}^{-1}$ ) was $17 \%$ higher $(\mathrm{p}<0.001)$ than that at 0.18 and $18.7 \mathrm{psu}\left(0.109 \pm 0.019 \mu \mathrm{g} \mathrm{O}_{2}\right.$ ind. $\left.{ }^{-1} \mathrm{~h}^{-1}\right)$, there were no statistical differences $(p>0.05)$ in the weight-specific respiration rates at all salinities studied (Table 1).

In females and males of Calanipeda aquaedulcis, respiration rates $(0.079 \pm 0.011$ and $0.057 \pm 0.009 \mu \mathrm{g}$ $\mathrm{O}_{2}$ ind..$^{-1} \mathrm{~h}^{-1}$, respectively) were significantly higher (30 and $40 \%$; p < 0.001) at 0.1 psu than at $18 \mathrm{psu}_{\text {; }}$ however, there were no statistical differences $(p>$ 0.05 ) between the weight-specific respiration rates of females and males of these species at $0.1,18$, and $40 \mathrm{psu}$.

\section{Effect of salinity on copepod sinking speed and body mass density}

At $18.3 \mathrm{psu}$, sinking speed of Arctodiaptomus salinus $\mathrm{O}_{\mathrm{II}}$ females (abdomen down and antennules spread) was $0.23 \pm 0.04 \mathrm{~cm} \mathrm{~s}^{-1}$ and did not differ sig- 
Table 1. Arctodiaptomus salinus and Calanipeda aquaedulcis. Respiration rates at different salinities expressed as the rate per capita $(R)$ and as the wet weight-specific rate $(R / \mathrm{WW})$ at an experimental temperature of $20 \pm 0.5^{\circ} \mathrm{C}$. $\mathrm{n}$ : number of experiments. Values are means $\pm \mathrm{SD}$

\begin{tabular}{|c|c|c|c|c|}
\hline $\begin{array}{l}\text { Salinity } \\
\text { (psu) }\end{array}$ & $\mathrm{n}$ & $\begin{array}{l}\text { Wet weight, WW } \\
\text { (mg) }\end{array}$ & $\begin{array}{c}\text { Respiration rate, } R \\
\left(\mu \mathrm{O}_{2} \text { ind. }^{-1} \mathrm{~h}^{-1}\right)\end{array}$ & $\begin{array}{c}R / W W \\
\left(\mu \mathrm{O} \mathrm{O}_{2} \mathrm{mg}^{-1} \mathrm{~h}^{-1}\right)\end{array}$ \\
\hline \multicolumn{5}{|c|}{ A. salinus, female } \\
\hline 0.18 & 10 & $0.096 \pm 0.024$ & $0.109 \pm 0.016$ & $1.11 \pm 0.18$ \\
\hline 18.7 & 30 & $0.108 \pm 0.011$ & $0.109 \pm 0.019$ & $1.02 \pm 0.17$ \\
\hline 39.2 & 6 & $0.115 \pm 0.017$ & $0.131 \pm 0.018$ & $1.15 \pm 0.25$ \\
\hline \multicolumn{5}{|c|}{ C. aquaedulcis, female } \\
\hline 0.1 & 11 & $0.049 \pm 0.007$ & $0.079 \pm 0.011$ & $1.59 \pm 0.25$ \\
\hline 1.0 & 2 & $0.046 \pm 0.004$ & $0.064 \pm 0.008$ & $1.38 \pm 0.17$ \\
\hline 18.0 & 31 & $0.042 \pm 0.009$ & $0.055 \pm 0.011$ & $1.32 \pm 0.33$ \\
\hline 40.0 & 6 & $0.048 \pm 0.005$ & $0.069 \pm 0.015$ & $1.45 \pm 0.45$ \\
\hline \multicolumn{5}{|c|}{ C. aquaedulcis, male } \\
\hline 0.1 & 7 & $0.020 \pm 0.003$ & $0.057 \pm 0.009$ & $3.02 \pm 0.52$ \\
\hline 1.0 & 2 & $0.019 \pm 0.003$ & $0.040 \pm 0.004$ & $2.08 \pm 0.18$ \\
\hline 18.0 & 20 & $0.014 \pm 0.001$ & $0.034 \pm 0.014$ & $2.37 \pm 0.96$ \\
\hline 40.0 & 4 & $0.015 \pm 0.005$ & $0.055 \pm 0.023$ & $3.76 \pm 1.61$ \\
\hline
\end{tabular}

nificantly $(\mathrm{p}>0.05)$ from the sinking speed of $\mathrm{O}_{\mathrm{II}}$ females acclimated for $1 \mathrm{wk}$ to $0.18 \mathrm{psu}(0.23 \pm 0.03$ $\left.\mathrm{cm} \mathrm{s}^{-1}\right)$ and $39.2 \mathrm{psu}\left(0.20 \pm 0.04 \mathrm{~cm} \mathrm{~s}^{-1}\right)$ at the same temperature $\left(22.5^{\circ} \mathrm{C}\right)$. However, mean body mass density, which was $1.052 \pm 0.006 \mathrm{~g} \mathrm{~cm}^{-3}$ at $18.3 \mathrm{psu}$, significantly $(\mathrm{p}<0.001)$ decreased to $1.039 \pm 0.004 \mathrm{~g}$ $\mathrm{cm}^{-3}$ with a salinity decrease down to $0.18 \mathrm{psu}$ and, in contrast, increased to $1.062 \pm 0.006 \mathrm{~g} \mathrm{~cm}^{-3}$ with a

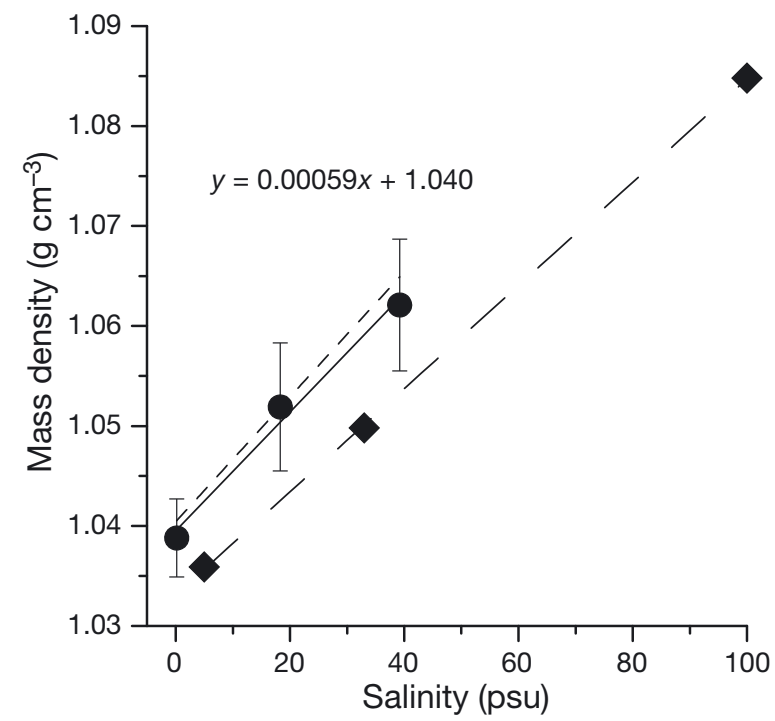

Fig. 2. Arctodiaptomus salinus. Effect of salinity on body mass density of females reared at $18 \mathrm{psu}(\bullet)$. Short-dashed line: theoretical change in body mass density in the case of ideal osmoconformity of $A$. salinus with a water content of $75.9 \%$ of the body volume. For comparison, the long-dashed line with diamonds shows the relationship between body mass density and salinity in Tigriopus brevicornis (McAllen et al. 1998). Values are means $\pm \mathrm{SD}$ salinity increase up to 39.2 psu with a linear correlation described by the equation $\rho_{\mathrm{b}}=0.00059 S+1.040$ (Fig. 2).

In Calanipeda aquaedulcis, orientation of the body and position of the antennules against the body axis was definitively correlated with water salinity. At low salinity, anesthetized females principally folded their antennules along the body and sank in the water head down due to gravity. At intermediate (18 psu) and high (30$40 \mathrm{psu}$ ) salinities, narcotized females sank mainly with the body orientated horizontally with the dorsal side down and the antennules spread. At that horizontal position, the sinking speed of $C$. aquaedulcis females varied insignificantly $(p>0.05)$ from $0.094 \pm$ 0.026 to $0.118 \pm 0.011 \mathrm{~cm} \mathrm{~s}^{-1}$ in the salinity range of 0.25 to $42.5 \mathrm{psu}$. In contrast, mean body mass density decreased in $1 \mathrm{~d}$ after salinity decrease from 18.1 to $2.3 \mathrm{psu}$ (Day 1), and then down further from 2.3 to $0.25 \mathrm{psu}$ (Day 2) from $1.067 \pm 0.006$ to $1.055 \pm 0.004$ and $1.053 \pm 0.007 \mathrm{~g} \mathrm{~cm}^{-3}$, respectively, and increased to $1.077 \pm 0.005$ and $1.079 \pm$ $0.007 \mathrm{~g} \mathrm{~cm}^{-3}$ in $1 \mathrm{~d}$ after salinity increase from 18.1 to 39.2 psu (Day 1) and 42.5 psu (Day 2) (Fig. 3). The linear equation for this correlation was $\rho_{\mathrm{b}}=0.00060 \mathrm{~S}$ +1.054 .

Mass density of Calanipeda aquaedulcis females was $1.042 \pm 0.009 \mathrm{~g} \mathrm{~cm}^{-3}$ after 1 mo of acclimation at $0.2 \mathrm{psu}$, and $1.064 \pm 0.007 \mathrm{~g} \mathrm{~cm}^{-3}$ after $1 \mathrm{wk}$ of maintenance at $40 \mathrm{psu}$. In $C$. aquaedulcis females kept at $22^{\circ} \mathrm{C}$ and $18 \mathrm{psu}$, mass density decreased from $1.067 \pm 0.006$ to $1.055 \pm 0.002 \mathrm{~g} \mathrm{~cm}^{-3}$ after $2 \mathrm{~d}$ of starvation and to $1.040 \pm 0.0055 \mathrm{~g} \mathrm{~cm}^{-3}$ after $8 \mathrm{~d}$ of starvation, whereas sinking speed decreased from $0.145 \pm 0.019$ to $0.107 \pm 0.01$ and $0.074 \pm 0.0096 \mathrm{~cm}$ $\mathrm{s}^{-1}$, respectively.

A gradual salinity increase over $8 \mathrm{~h}$ from 18.0 to 42.5 psu caused a linear increase in the mass density of females starved for $8 \mathrm{~d}$ to $1.053 \pm 0.002 \mathrm{~g} \mathrm{~cm}^{-3}$ in accordance with the equation $\rho_{\mathrm{b}}=0.00053 S+1.030$.

\section{Effect of salinity on egg mass density}

Our results summarized in Table 2 show that at $18.2 \mathrm{psu}$, the mass density of subitaneous eggs was significantly $(\mathrm{p}<0.001)$ higher in Calanipeda aquaedulcis $\left(1.074 \pm 0.009 \mathrm{~g} \mathrm{~cm}^{-3}\right)$ than in Arctodiaptomus salinus $\left(1.061 \pm 0.006 \mathrm{~g} \mathrm{~cm}^{-3}\right)$. The mass density of 


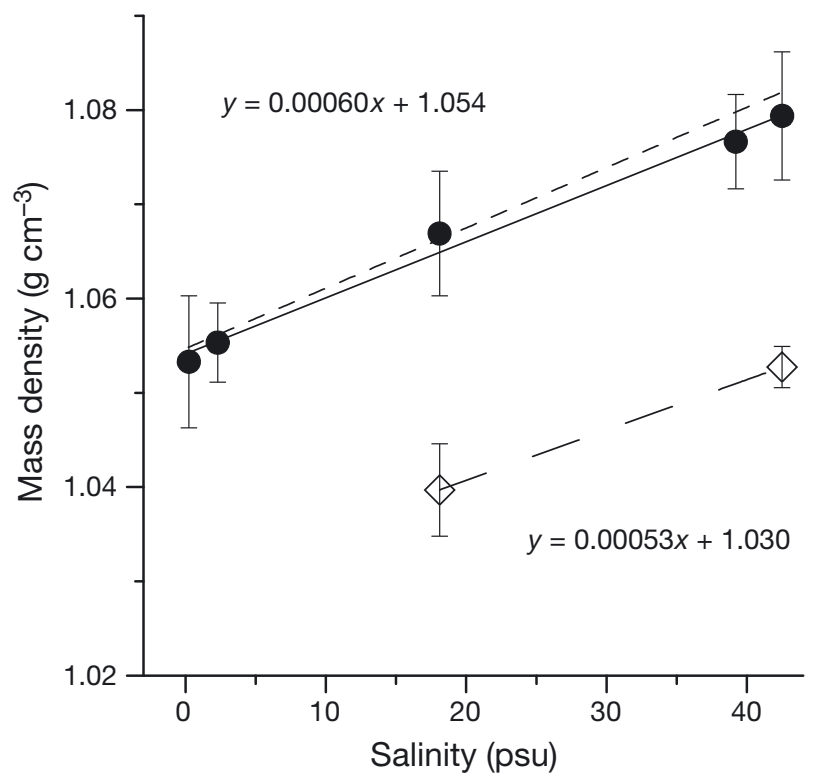

Fig. 3. Calanipeda aquaedulcis. Effect of salinity on body mass density of females reared at $18 \mathrm{psu}$ and fed with algae ad libitum $(\bullet$, solid line) and after $8 \mathrm{~d}$ of starvation $(\diamond$, longdashed line). Short-dashed line: theoretical change in body mass density in the case of ideal osmoconformity of $C$. aquaedulcis with a water content of $80.7 \%$ of the body volume. Values are means $\pm \mathrm{SD}$

resting grey $\left(1.077 \pm 0.007 \mathrm{~g} \mathrm{~cm}^{-3}\right)$ and resting pink $\left(1.087 \pm 0.005 \mathrm{~g} \mathrm{~cm}^{-3}\right)$ eggs of $A$. salinus was significantly $(\mathrm{p}<0.001)$ higher than that of subitaneous eggs.

Table 2. Arctodiaptomus salinus and Calanipeda aquaedulcis. Mass density of subitaneous and resting eggs of $A$. salinus and subitaneous eggs of $C$. aquaedulcis at different salinities and $22 \pm 0.5^{\circ} \mathrm{C}$. Values are means $\pm \mathrm{SD}$

\begin{tabular}{|lcccc|}
\hline $\begin{array}{l}\text { Species } \\
\text { Egg type }\end{array}$ & $\begin{array}{c}\text { Salinity } \\
\text { of culture } \\
(\mathrm{psu})\end{array}$ & $\begin{array}{c}\text { Experimen- } \\
\text { tal salinity } \\
(\mathrm{psu})\end{array}$ & $\begin{array}{c}\text { Egg } \\
\text { diameter } \\
(\mu \mathrm{m})\end{array}$ & $\begin{array}{c}\text { Mass } \\
\text { density } \\
\left(\mathrm{g} \mathrm{cm}^{-3}\right)\end{array}$ \\
\hline $\begin{array}{l}\text { A. salinus } \\
\text { Subitaneous }\end{array}$ & 0.2 & 0.2 & $144 \pm 7$ & $1.046 \pm 0.003$ \\
& 18.2 & $0.2^{\mathrm{a}}$ & $140 \pm 8$ & $1.058 \pm 0.005$ \\
& 18.2 & $2.3^{\mathrm{b}}$ & $143 \pm 7$ & $1.053 \pm 0.003$ \\
& 2.3 & $18.2^{\mathrm{a}}$ & $138 \pm 4$ & $1.049 \pm .0002$ \\
& 2.3 & $18.2^{\mathrm{b}}$ & $134 \pm 6$ & $1.063 \pm 0.007$ \\
Resting grey & 18.2 & 18.2 & $144 \pm 7$ & $1.061 \pm 0.006$ \\
& 0.2 & 0.2 & $148 \pm 11$ & $1.067 \pm 0.008$ \\
Resting pink & 18.2 & $18.0^{\mathrm{a}}$ & $143 \pm 7$ & $1.076 \pm 0.004$ \\
& 18.2 & 18.2 & $143 \pm 6$ & $1.077 \pm 0.007$ \\
C. aquaedulcis & 18.2 & $138 \pm 6$ & $1.087 \pm 0.005$ \\
Subitaneous & 18.2 & 18.2 & $108 \pm 7$ & $1.074 \pm 0.009$ \\
a Just after gradual salinity change; ${ }^{\mathrm{b}} 1 \mathrm{~d}$ after gradual salinity change \\
\hline
\end{tabular}

At $0.2 \mathrm{psu}$, mass densities of subitaneous and resting eggs $\left(1.046 \pm 0.003\right.$ and $1.067 \pm 0.008 \mathrm{~g} \mathrm{~cm}^{-3}$, respectively) of Arctodiaptomus salinus were significantly ( $\mathrm{p}<0.001$ ) lower than those at $18.2 \mathrm{psu}$.

A salinity increase from 0.2 to $18 \mathrm{psu}$ at a rate of 2 to $3 \mathrm{psu} \mathrm{h}^{-1}$ resulted in a significant $(\mathrm{p}<0.001)$ abrupt increase in the density of resting eggs laid in fresh water, up to $1.076 \pm 0.004 \mathrm{~g} \mathrm{~cm}^{-3}$. In contrast, significant changes in the density of subitaneous eggs laid by Arctodiaptomus salinus at 18.2 psu were found only in the $24 \mathrm{~h}$ after their gradual transition to 0.2 psu (Table 2), and after the reverse gradual transition to $18.2 \mathrm{psu}$ at the same rate $\left(2\right.$ to $3 \mathrm{psu} \mathrm{h}^{-1}$ ).

\section{DISCUSSION}

\section{Salinity tolerance of Calanipeda aquaedulcis and Arctodiaptomus salinus}

Calanipeda aquaedulcis and Arctodiaptomus salinus are representatives of the 2 'closest relatives': the families Pseudodiaptomidae and Diaptomidae (Grindley 1984). According to Grindley (1984), C. aquaedulcis originated from the sea and represents an intermediate stage in adaptation to freshwater environments (mainly coastal and estuarine areas). A. salinus is well adapted to highly mineralized inland water bodies. Despite these differences, the salinity ranges of their habitats are similar. In the brackish Black, Azov, and Caspian Seas (Garber 1951, Kovalev et al. 2006), C. aquaedulcis is found at salinities of 6 to $18 \mathrm{psu}$, whereas in the coastal waters of the Mediterranean Sea, it is distributed within a salinity range of 7 to 35 psu (Ramdani et al. 2001, Brucet et al. 2006, Alfonso \& Belmonte 2011). This species occurred in the Aral Sea at 12 psu but disappeared when salinity increased to $57 \mathrm{psu}$ (Aladin \& Plotnikov 2008). A. salinus inhabits temporary salt lakes of Spain at salinities higher than 7 psu (Comin \& Alonso 1988), and up to 25.5 psu (Jiménez-Melero et al. 2007). High salinity (up to $40 \mathrm{psu}$ ) is typical for the habitats of $A$. salinus in permanent inland waters of Sicily (Marrone et al. 2006) and temporary salt marshes of Morocco (Rokneddine \& Chentoufi 2004), as well as in salt lakes of the Eastern Crimea (Shadrin et al. 2008) and Siberia (Ermolaeva 2010, Tolomeev et al. 2010).

Such osmotic relations of organisms with their environment characterize primary mar- 
ine euryhaline osmoconformers that have a salinity tolerance range of 8 to 40 psu (Khlebovich \& Aladin 2010). Those authors considered salinities of 5 to $8 \mathrm{psu}$ as the critical values limiting the distribution of marine species. However, our experimental data on median lethal salinity $\left(\mathrm{LS}_{50}\right.$ ) of Calanipeda aquaedulcis and Arctodiaptomus salinus acclimated to $18 \mathrm{psu}$ showed that their salinity ranges were within 0.2 to 50 and 0.2 to 35 psu, respectively (Fig. 1). It is important to emphasize that such a wide range of salinity tolerance in these species is apparently genetically determined, as they were maintained at a constant salinity of $18 \mathrm{psu}$ for longer than $4 \mathrm{yr}$ before the experiment.

In the freshwater treatments, copepods actively fed on the freshwater alga Haemotococcus pluvialis and laid eggs that hatched into viable nauplii. We did not find any significant differences in the swimming rate of copepods (L. Svetlichny et al. unpubl.) acclimated to fresh and brackish water (18 psu). In Calanipeda aquaedulcis and Arctodiaptomus salinus acclimated to fresh water, mortality did not exceed the $50 \%$ level $\left(\mathrm{LS}_{50}\right)$ during salinity changes from 0.2 to $30 \mathrm{psu}$ and from 0.2 to ca. 18 psu, respectively (Fig. 1). Thus in our experiments, C. aquaedulcis reared both in fresh and brackish water could tolerate gradual salinity changes up to $30 \mathrm{psu}$, whereas A. salinus tolerated only salinity alterations limited to a range of about 18 psu. For comparison, Pseudodiaptomus annandalei from a lagoon near Wukan Bay tolerated gradual salinity increases from 22 to 35 psu and decreases from 22 to 5 psu (Chen et al. 2006). Acartia tonsa (Lance 1963, Cervetto et al. 1999, Hubareva et al. 2008) and Eurytemora affinis (Lee \& Petersen 2003) successfully survived gradual salinity changes over 20 psu under experimental conditions.

The extremely wide range of salinity tolerance in Calanipeda aquaedulcis ( 0.2 to $50 \mathrm{psu}$ ) can be compared with the resistance to salinity alterations in intertidal harpacticoids from the genera Tigriopus and Tisbe living in the range of 0 to 60 psu (Finney 1979) and the calanoid Eurytemora affinis surviving in a salinity range of 0 to 40 psu (Roddie et al. 1984, Lee et al. 2007). However, a wide salinity tolerance range in harpacticoid Copepoda is due to inorganic (Battaglia \& Bryan 1964) and biochemical osmoregulation, when intracellular organic osmolytes are used for the regulation of cell volume in response to changes in salinity (Goolish \& Burton 1989).

Despite the fact that up to $15 \%$ of Calanipeda aquaedulcis specimens survived during their maintenance at 60 psu for $10 \mathrm{~d}$, and some Arctodiaptomus salinus specimens survived for more than $14 \mathrm{~d}$ at salinities up to $70 \mathrm{psu}$, we did not observe hatching of nauplii from the ovisacs of $A$. salinus and $C$. aquaedulcis females at salinities higher than 50 psu. This was likely due to osmotic effects during hatching. Copepod nauplii emerged from eggs after cracking of the outer membrane caused by active absorption of water through the inner membrane (Marshall \& Orr 1972). Apparently, the hatching process is inhibited in eggs of $A$. salinus and $C$. aquaedulcis at salinities higher than 50 psu due to osmotic effects. According to Rokneddine \& Chentoufi (2004), the reproductive potential of $A$. salinus from the Zima salt marsh in Morocco decreased 5-fold with a salinity increase to the upper boundary of its tolerance range (35 psu). In other estuarine holoplanktonic copepods, the critical salinity for survival of their juvenile stages was also found to be rather low: 20 psu (Ishikawa et al. 1999) and 25 psu (Lee et al. 2007) in Eurytemora affinis, and 35 psu in Pseudodiaptomus annandalei (Chen et al. 2006).

\section{Effect of salinity on adult respiration rate}

The results of numerous studies investigating the effect of salinity on respiration rates of copepods are contradictory (Anraku 1964, Gyllenberg \& Lundqvist 1978, Newrkla 1978, Roddie et al. 1984, Goolish \& Burton 1989, McAllen \& Taylor 2001, Isla \& Perissinotto 2004, Calliari et al. 2006) and cannot be explained without taking into account the energy expenditure for osmoregulation and locomotory activity of the animals. Theoretically, the minimum osmotic work for ion transport constitutes only $1 \%$ of the total metabolic energy requirements in brackish and freshwater animals (Potts 1954). However, Goolish \& Burton (1989) showed that the daily energy required for adjusting metabolism to osmotic stress in Tigriopus californicus acclimated to constant salinity amounted to $11.6 \%$ of the total energy respired. Generally, in copepods, total metabolism of active individuals exceeds 3 to 6 -fold the basal metabolism of immobilized individuals (Svetlichny \& Hubareva 2005); therefore, adaptive changes in locomotory activity of copepods should affect respiration to a greater extent than the process of osmoregulation.

According to McAllen \& Taylor (2001), both oxygen consumption rate and activity level decreased 2 -fold in Tigriopus brevicornis exposed to a salinity increase from 33 to 90 psu, suggesting a decrease in energy requirements for sustained locomotion in more saline water. Earlier, McAllen et al. (1998) demonstrated that $T$. brevicornis was an exception- 
ally euryhaline osmoconformer over the range of 10 to 100 psu. However, McAllen \& Taylor (2001) showed that there were signs of osmoregulation in $T$. brevicornis at the lowest salinities tolerated by this species (5 psu).

Although in our experiments the respiration rate of Arctodiaptomus salinus females was $17 \%$ higher at 39.2 psu than at 0.18 or 18.7 psu, weight-specific respiration rates showed no significant differences at all salinities in the range 0.18 to $39.2 \mathrm{psu}$. Also, there was no evidence of salinity-associated differences in weight-specific respiration rates of Calanipeda aquaedulcis females and males at 0.1, 18.7, and $40 \mathrm{psu}$. The obtained accuracy of mean weightspecific oxygen consumption rates ranged from 16 to $22 \%$ coefficient of variation (CV) in A. salinus females, 12 to $31 \% \mathrm{CV}$ in C. aquaedulcis females, and 8 to $41 \% \mathrm{CV}$ in C. aquaedulcis males. The lastmentioned accuracy (8 to $41 \% \mathrm{CV}$ ) seems to be too low to claim an osmoregulatory capacity in the studied copepods, as it is comparable with the cost of this process $(11.6 \%$ of the total energy respired) in Tigriopus californicus (Goolish \& Burton 1989), but it is sufficient to conclude the absence of a salinity impact on their locomotory activities.

\section{Effect of salinity on body mass density, sinking speed, and density contrast}

Lowndes (1942) and Gross \& Raymont (1942) were the first to measure mass density of copepods. For this purpose, Lowndes (1942) weighed a batch of adult copepods using 'density bottles' of $0.5 \mathrm{ml}$. The results obtained for 4 copepod species were converted to a 'sinking factor,' which is the same as the density contrast between the organisms and seawater multiplied by 1000 (Knutsen et al. 2001). Gross \& Raymont (1942) determined the mass density of a single Calanus finmarchicus using the density bottle method, introducing the copepods to different mixtures of gum arabic and seawater of given density. Usually, with the density bottle method, the organisms are killed or anesthetized, and then a liquid of a certain density where the organisms are neutrally buoyant must be found (Aleyev \& Khvorov 1985). For the measurement of copepod body mass density, McAllen et al. (1998) used a solution of sea salts and deionized water. The density bottle method introducing adult copepods to different mixtures of seawater and glycerol was also used by Greenlaw (1977) and Matsukura et al. (2009). Køgeler et al. (1987) and Visser \& Jonasdottir (1999) used the density gradient column method with solutions of diluted seawater and sugar. The density contrast of antarctic copepods was measured using a dual-density method (Chu \& Wiebe 2005), where the densities of 2 fluids (natural seawater and distilled water) without copepods and mixtures of the fluids with copepods were determined. However, using hyper- or hypo-osmotic solutions might force the water in the body of a copepod to be transported across the cell membranes, causing changes in body weight and volume.

Lowndes (1942) raised the question of errors due to osmotic imbalance between the solution and the organism changing the relative water content of the body tissues. To determine mass density of zooplankton, Greenlaw \& Johnson (1982) proposed to use a hypotonic solution of distilled water and colloidal silica. They observed no apparent changes in the buoyancy of live or preserved zooplankton organisms over time spans of seconds to minutes.

To exclude osmotic factors, Knutsen et al. (2001) used the Stokes hydrodynamic equation modified for the sinking of an elongated ellipsoid in water to calculate the mass density of Calanus finmarchicus and C. glacialis. Prior to the measurement of sinking speed, the antennae of each anesthetized animal were removed from the body to conform to the ellipsoidal shape. Previously, a similar method was used to determine mass density in 16 copepod species (Svetlichny 1981) based on an empirical study of species-specific hydrodynamic drag coefficients $\left(C_{\mathrm{D}}\right)$ determined during experiments with passive sinking of immobilized individuals that had been weighed in seawater using a special microbalance (Svetlichny 1983b).

In this study, we recalculated the hydrodynamic data of Svetlichny (1983b) and expressed $C_{\mathrm{D}}$ in the form of the power regression equation $C_{\mathrm{D}}=c / \mathrm{Re}^{n}$, where $n$ is the regression slope and $c$ is the hydrodynamic shape factor depending on the ratio of $l_{\mathrm{an}} l_{\mathrm{pr}}: d_{\mathrm{pr}}^{2}$ and body position during sinking (see 'Materials and methods' and the supplement at www. int-res.com/articles/suppl/m470p015_supp.pdf). Using $C_{\mathrm{D}}$ and body volume calculated from the relation $V_{\mathrm{b}}$ $\sim L^{0.21} I_{\mathrm{pr}}^{0.93} d_{\mathrm{pr}}^{1.86}$ (see 'Materials and methods' and the supplement), we can determine mass density of the majority of calanoids or cyclopoids with body shapes varying from spherical with short antennules to elongated ellipsoids with very long antennules, taking into account only the values of sinking speed in the water and $L, l_{\mathrm{an}}, l_{\mathrm{pr}}$ and $d_{\mathrm{pr}}$ parameters. Despite the fact that the methods mentioned above (see 'Discussion' in Knutsen et al. 2001) should be treated as indicative rather than absolute, measure- 


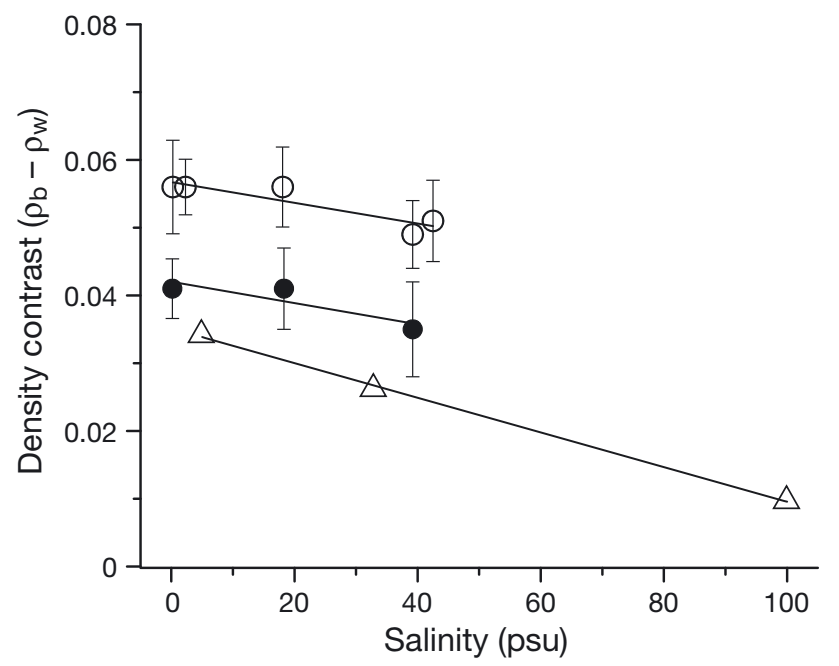

Fig. 4. Arctodiaptomus salinus, Calanipeda aquaedulcis, and Tigriopus brevicornis. Effect of salinity on density contrast of A. salinus (O) and $C$. aquaedulcis $(O)$ reared at $18 \mathrm{psu}$, and for comparison, $T$. brevicornis $(\triangle$, calculated from McAllen et al. 1998). Values are means \pm SD

ments on the basis of sinking speed allow the determination of copepod mass density with respect to their natural seawater habitat.

According to our results, the mass density in Calanipeda aquaedulcis acclimated to $18 \mathrm{psu}$ increased from $1.053 \pm 0.007$ to $1.079 \pm 0.007 \mathrm{~g} \mathrm{~cm}^{-3}$ with a gradual increase in salinity in the range of 0.2 to 42.5 psu whilst that in Arctodiaptomus salinus increased from $1.039 \pm 0.004$ to $1.062 \pm 0.006 \mathrm{~g} \mathrm{~cm}^{-3}$ in the range of 0.2 to $39.2 \mathrm{psu}$. During no less than $1 \mathrm{wk}$ at extreme salinities, the mass density in both species remained nearly the same. Unlike mass density, density contrast in the studied species did not differ significantly $(p>0.05)$ in the same salinity ranges and amounted to $0.056 \pm 0.007$ and $0.051 \pm$ 0.006 at 0.2 and 42.5 psu, respectively, in C. aquaedulcis, and $0.041 \pm 0.005$ and $0.035 \pm 0.007$ at 0.18 and 39.2 psu, respectively, in A. salinus (Fig. 4), indicating osmoconformity of these species. To examine the possibility of iso-osmoticity in these species, we calculated theoretically expected changes in the mass density of the studied copepods when body fluid was iso-osmotic to the surrounding water. For C. aquaedulcis and A. salinus reared at $18.0 \mathrm{psu}$ and $22^{\circ} \mathrm{C}$, measured values of dry weight $(0.0077$ and $0.0254 \mathrm{mg}$ ) were equal to 19.3 and $24.1 \%$ of the values of wet weight $(0.0400$ and $0.1053 \mathrm{mg})$, and water content amounted to 80.7 and $75.9 \%$ of the mean wet weight and 85.1 and $79.1 \%$ of the body volume $\left(0.0375\right.$ and $\left.0.1001 \mathrm{~mm}^{3}\right)$, respectively. This is in accordance with the values of water content in other copepods (Ikeda et al. 1990, 2004, 2006).
In euryhaline copepods, rapid salinity changes result in adaptive compensatory alterations in the body volume (Goolish \& Burton 1989, McAllen et al. 1998). However, according to Goolish \& Burton (1989), the body volume of Tigriopus californicus recovered in $1 \mathrm{~h}$ following hyperosmotic stress and $4 \mathrm{~h}$ after hypoosmotic stress.

We did not find significant differences between the values of body size and volume in Calanipeda aquaedulcis and Arctodiaptomus salinus after a gradual salinity increase in the range of 0.2 to $40 \mathrm{psu}$ and 0.18 to $39.2 \mathrm{psu}$, respectively. The mass densities of $C$. aquaedulcis and A. salinus calculated (within these salinity ranges) under the assumptions that body volume is constant and that water content is iso-osmotic to the surrounding water, are within the limits of 1.055 to 1.081 and 1.040 to $1.065 \mathrm{~g} \mathrm{~cm}^{-3}$, respectively, which are close to measured values (Figs. $2 \& 3$ ).

In Tigriopus brevicornis, mass density also linearly increased from 1.036 to $1.085 \mathrm{~g} \mathrm{~cm}^{-3}$ (McAllen et al. 1998) with a salinity increase from 5 to $100 \mathrm{psu}$ (Fig. 2). Based on the pattern of changes in the osmolality of the body fluids, the authors considered this species to be a euryhaline osmoconformer. However, according to data presented by McAllen et al. (1998, their Table 2) on water and body density, the density contrast of $T$. brevicornis uniformly decreased 1.3-fold in the range of 5 to $33 \mathrm{psu}$ and 3.5 -fold in the range of 5 to 100 psu (Fig. 2) because body density increased more slowly than water density during the salinity increase. This result and the low slope of the regression line of the sodium ion in T. brevicornis (McAllen et al. 1998, their Fig. 2) indicate that this species is not an ideal conformer. In contrast, Eurytemora affinis (Seuront 2006) did not exhibit any significant differences between sinking speeds of males, non-ovigerous females, and ovigerous females in the salinity range of 0 to $35 \mathrm{psu}$, indicating that this species is as strong an osmoconformer as Calanipeda aquaedulcis and ArCtodiaptomus salinus.

\section{Mass density and dry weight changes during starvation in Calanipeda aquaedulcis}

Mean mass density of copepods of all species depends on such things as their body composition, characteristics of their life cycle, feeding, starvation, and stresses. In deep-water copepods of the genus Calanus that accumulate wax esters in the oil sac before diapause, the mass density decreased from 


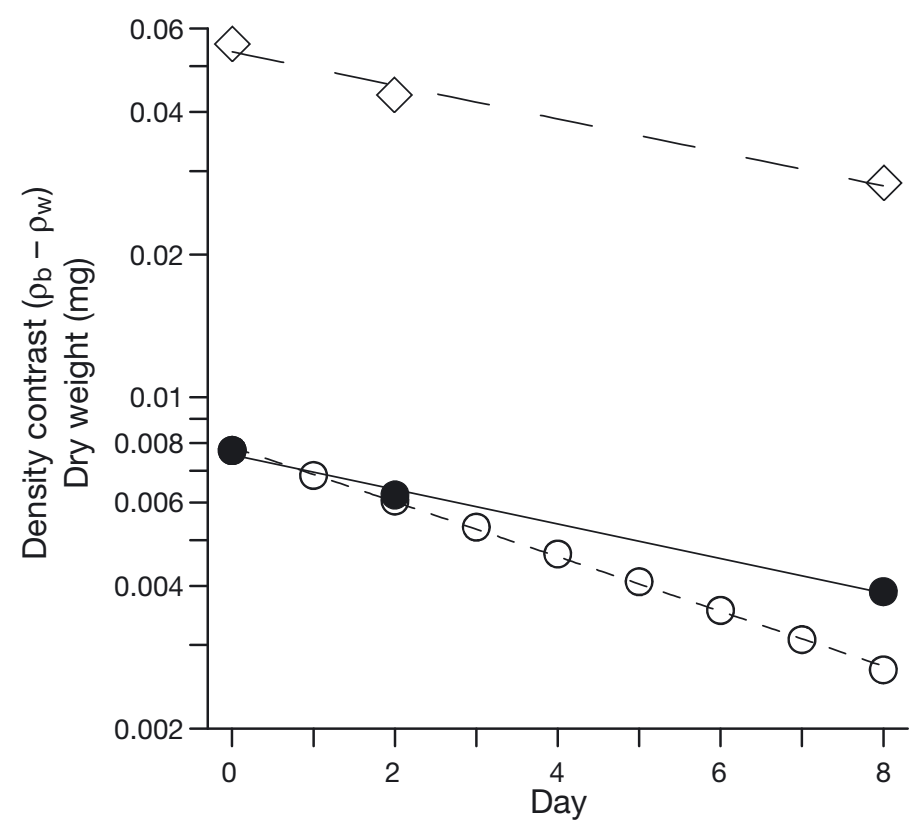

Fig. 5. Calanipeda aquaedulcis. Changes in density contrast $(\diamond$, long-dashed line) and body dry weight calculated on the basis of body mass density (, , solid line) and respired energy losses converted to dry weight $(\mathrm{O}$, dashed line) during starvation

1.06 to $0.99 \mathrm{~g} \mathrm{~cm}^{-3}$ with an increase in lipid content at seawater density of $1.016 \mathrm{~g} \mathrm{~cm}^{-3}$ (Svetlichny et al. 1998) and from 1.052 to $1.025 \mathrm{~g} \mathrm{~cm}^{-3}$ at seawater density of about $1.022 \mathrm{~g} \mathrm{~cm}^{-3}$ (Visser \& Jonasdottir 1999). Hence, individuals with a lipid content of $60 \%$ of dry weight in the Black Sea or $30 \%$ of dry weight in the Norwegian Sea may have neutral buoyancy. Wax esters are accumulated slowly and could be involved in metabolic processes as a last energy resource, later than other lipids, probably allowing calanoid copepods to keep positive buoyancy during longterm diapause. Estuarine and freshwater copepods (including Arctodiaptomus salinus and Calanipeda aquaedulcis) accumulate mainly triacylglycerols in the form of droplets distributed in the body (Ventura \& Catalan 2005, Guerrero et al. 2007, Tolomeev et al. 2010). However, in contrast to wax esters, triacylglycerols can be rapidly synthesized during feeding and utilized at starvation, thus influencing the body mass density. The pattern of changes in the mass density due to losses of low-density and high-density body components may indicate a metabolic path used during starvation.

According to our results, the mass density of Calanipeda aquaedulcis at $22^{\circ} \mathrm{C}$ decreased from $1.067 \pm$ 0.006 to $1.055 \pm 0.002 \mathrm{~g} \mathrm{~cm}^{-3}$ after $2 \mathrm{~d}$ of starvation and to $1.040 \pm 0.005 \mathrm{~g} \mathrm{~cm}^{-3}$ after $8 \mathrm{~d}$ of starvation. During the entire period of starvation, sinking speed and density contrast decreased about 2-fold from 0.145 to $0.074 \mathrm{~cm} \mathrm{~s}^{-1}$ and from 0.0555 to $0.0283 \mathrm{~g}$ $\mathrm{cm}^{-3}$, respectively (Fig. 5), while body volume did not change significantly. Consequently, if during starvation only low-density lipids were utilized, the mass density would increase due to uptake of water. Thus, the decrease in mass density could occur as a result of utilization of high-density body components such as proteins with densities $>1.35 \mathrm{~g} \mathrm{~cm}^{-3}$.

We estimated the dry weight (DW) losses in Calanipeda aquaedulcis (corresponding to changes in the mass density during starvation) by accepting their initial DW as $0.0077 \mathrm{mg}(19.3 \%$ of WW, see above, this section) and body volume of $0.038 \mathrm{~mm}^{3}$. DW was equal to $0.0062 \mathrm{mg}$ after $2 \mathrm{~d}$ of starvation and $0.0039 \mathrm{mg}$ after $8 \mathrm{~d}$ of starvation. To examine estimated DW losses, we calculated the expected losses in DW during starvation of C. aquaedulcis in accordance with their respired energy. The mean respiration rate in $C$. aquaedulcis (our results) at $20^{\circ} \mathrm{C}$ was $0.055 \mu \mathrm{g} \mathrm{O}_{2}$ ind. $^{-1} \mathrm{~h}^{-1}$ (or $0.041 \mu \mathrm{mol} \mathrm{O}_{2}$ ind..$^{-1} \mathrm{~d}^{-1}$ ). So, according to the temperature coefficient for copepods $\left(Q_{10}=2.0\right)$ formulated by Ikeda et al. (2001), mean respiration rate in $C$. aquaedulcis at $22^{\circ} \mathrm{C}$ would be $0.048 \mu \mathrm{mol} \mathrm{O}$ ind. $^{-1} \mathrm{~h}^{-1}$.

To convert the daily consumed oxygen into energy units, we can use the oxyenthalpic equivalent of $480 \mathrm{~kJ} \mathrm{~mol}^{-1} \mathrm{O}_{2}$ (Gnaiger \& Forstner 1983), assuming that the combusted substrate was a mixture of lipids, proteins, and carbohydrates. To convert energy dissipation rate to DW losses, we used the copepod mean DW energy content of $26 \mathrm{~J} \mathrm{mg}^{-1}$ DW (Ikeda et al. 2006). Changes in respiration rate due to a decrease in DW were estimated according to the equation: $R_{t-1} / R_{t}=\left(\mathrm{DW}_{t-1} / \mathrm{DW}_{t}\right)^{0.8}$, where $t$ is time (d). Calculated this way, DW of starved Calanipeda aquaedulcis decreased during $8 \mathrm{~d}$ of starvation from 0.0077 to $0.0027 \mathrm{mg}$ with a higher regression slope than that calculated in accordance with changes in the body mass density (Fig. 5). This may be due to the fact that in starving animals, the respiration rate decreases more quickly than body weight.

Consequently, the indirect method of determining mass density based on sinking speed gives the opportunity to conduct long-term observations of live copepods and may be improved using video recordings of the behavior of intact individuals. For example, studies on changes in the mass density of dead copepods based on the sinking speed of carcasses allowed us to determine the decomposition rate in intact individuals inside conical tubes with constantly ascending seawater flows (Stepanov \& Svetlichny 1981). 


\section{Effects of salinity on egg mass density}

At $18 \mathrm{psu}$, the mass density of subitaneous eggs in Calanipeda aquaedulcis $\left(1.074 \pm 0.009 \mathrm{~g} \mathrm{~cm}^{-3}\right)$ was significantly $(\mathrm{p}<0.001)$ higher than in Arctodiaptomus salinus subitaneous eggs $\left(1.061 \pm 0.006 \mathrm{~g} \mathrm{~cm}^{-3}\right)$, and the density contrast in $C$. aquaedulcis eggs exceeded by $27 \%$ that in $A$. salinus subitaneous eggs. The same tendency was observed in females of these species $(1.067 \pm 0.006$ and $1.0529 \pm 0.006 \mathrm{~g}$ $\mathrm{cm}^{-3}$, respectively), probably due to higher lipid content in eggs and females of $A$. salinus. In comparison with the mass density of subitaneous eggs, mass density of resting eggs of $A$. salinus was significantly ( $p<$ 0.001 ) higher: $1.077 \pm 0.007$ and $1.087 \pm 0.005 \mathrm{~g} \mathrm{~cm}^{-3}$ in grey and pink eggs, respectively.

According to our data, the mass density of eggs was higher than the mass density of females and seawater. It is important to estimate the energy cost of bearing eggs in sac-spawning copepods. At $22.5^{\circ} \mathrm{C}$ and $18.3 \mathrm{psu}$, the sinking speed of non-ovigerous Arctodiaptomus salinus females was $0.23 \pm 0.04 \mathrm{~cm}$ $\mathrm{s}^{-1}$, whereas that of females with $12-14$ and 20 eggs in the ovisac was $0.286 \pm 0.021$ and $0.335 \pm 0.011 \mathrm{~cm}$ $\mathrm{s}^{-1}$, respectively, i.e. 1.46-fold higher. At a low Reynolds number, the hydrodynamic power $F$ is proportional to $U^{2}$, hence the cost of sustained locomotion in the heaviest $A$. salinus females due to a large egg sac will be approximately 2 -fold higher than that in non-egg-carrying females.

According to Seuront (2006), the sinking speed of ovigerous females of Eurytemora affinis was approximately 1.7-fold higher than that of non-ovigerous females at the same water salinity. The clutch size in this species reaches 75 eggs clutch ${ }^{-1}$ (Beyrend-Dur et al. 2009), which explains the stronger (compared to our data) difference between sinking speeds of nonovigerous and brooding females. Hence, the cost of the egg-brooding strategy in comparison with the broadcast strategy is likely to be increased due to energy demands for sustained locomotion and increased predation on adult females, since the large egg masses can cause a decrease in swimming speed (Seuront 2006).

To study the osmoregulatory ability in eggs of Arctodiaptomus salinus, we estimated changes in the mass density of resting and subitaneous eggs in the range of 0.2 to $18.2 \mathrm{psu}$. The mean mass density in resting eggs of $A$. salinus reared at 0.2 psu increased from 1.067 to $1.076 \mathrm{~g} \mathrm{~cm}^{-3}$ just after $6 \mathrm{~h}$ of a gradual salinity increase to $18.0 \mathrm{psu}$, while the density contrast $\left(0.069\right.$ and $0.065 \mathrm{~g} \mathrm{~cm}^{-3}$ at 0.2 and $18.2 \mathrm{psu}$, respectively) was nearly stable and similar to the density contrast in resting eggs of females reared at 18.2 psu (Table 2). To examine whether the changes in egg mass density conformed to the changes in the inner water mass density, we calculated the water content and density of dry mass of $A$. salinus resting eggs and compared the obtained values to the literature data. The water content $\left(C_{\mathrm{w}}\right)$ as a share of the egg volume can be determined by solving the following linear equations:

$$
\left\{\begin{array}{l}
\rho_{\mathrm{b} 1}=\left[\rho_{\mathrm{DM}} V_{\text {egg }}\left(1-C_{\mathrm{w}}\right)+\rho_{\mathrm{w} 1} V_{\text {egg }} C_{\mathrm{w}}\right] / V_{\text {egg }} \\
\rho_{\mathrm{b} 2}=\left[\rho_{\mathrm{DM}} V_{\text {egg }}\left(1-C_{\mathrm{w}}\right)+\rho_{\mathrm{w} 2} V_{\text {egg }} C_{\mathrm{w}}\right] / V_{\text {egg }}
\end{array}\right.
$$

where $\rho_{\mathrm{DM}}$ is the density of dry mass, $\rho_{\mathrm{w}}$ is the water density, and $V_{\text {egg }}$ is the egg volume, which is constant before and after salinity changes (see Table 2). The solution for $C_{\mathrm{w}}$ can be obtained as:

$$
C_{\mathrm{w}}=\left(\rho_{\mathrm{b} 1}-\rho_{\mathrm{b} 2}\right) /\left(\rho_{\mathrm{w} 1}-\rho_{\mathrm{w} 2}\right)
$$

The estimated value of $C_{\mathrm{w}}$ for resting eggs of Arctodiaptomus salinus was 0.67, and therefore $\rho_{\mathrm{DM}}$ was calculated as $1.207 \mathrm{~g} \mathrm{~cm}^{-3}$. In accordance with the obtained constant values of $C_{\mathrm{w}}$ and $\rho_{\mathrm{DM}}$, egg mass density at 0.2 and 18 psu should be 1.067 and $1.076 \mathrm{~g} \mathrm{~cm}^{-3}$, respectively, as it had been calculated from measured sinking speeds. For comparison, the mass density of resting eggs in the closely related Centropages tenuiremis at a salinity of 28 psu was equal to $1.1486 \mathrm{~g} \mathrm{~cm}^{-3}$ (Wang et al. 2005), while $C_{\mathrm{w}}$ and $\rho_{\mathrm{DM}}$ calculated from the values of DW (165 ng $\mathrm{egg}^{-1}$ ) and egg diameter $(79.69 \mu \mathrm{m})$ were 0.52 and $1.285 \mathrm{~g} \mathrm{~cm}^{-3}$, respectively.

The mean mass densities in subitaneous eggs of Arctodiaptomus salinus obtained from females reared at 0.2 and $18.2 \mathrm{psu}$ were also different (1.046 and $1.061 \mathrm{~g} \mathrm{~cm}^{-3}$, respectively, Table 2), whereas the values of density contrast showed no essential difference (0.048 and $0.049 \mathrm{~g} \mathrm{~cm}^{-3}$, respectively), as in resting eggs. However, in contrast to resting eggs, the changes in mass density of subitaneous eggs did not occur immediately after the changes in salinity of the surrounding water, suggesting a hysteresis response to salinity in this type of eggs.

\section{CONCLUSIONS}

According to our experimental results, the range of salinity tolerance (conditions under which the specimens survive and reproduce over a long period of time) is within 0.2 to 50 psu for Calanipeda aquaedulcis and within 0.2 to 35 psu for Arctodiaptomus salinus. Over a time period of about $8 \mathrm{~h}$, corresponding to the duration of tidal cycles, $C$. aquaedulcis and $A$. 
salinus can withstand gradual salinity alterations of about 30 and 18 psu, respectively. Adapted to survive at extreme low and high salinities, these species are potentially able to colonize both fresh and marine environments. The absence of changes in respiration rate and iso-osmotic changes in copepod body density revealed in our study are evidence of the capability of the studied species to acclimate to both fresh water and hypersaline conditions without special mechanisms of osmotic regulation. These findings are in disagreement with the existing opinion that the salinity tolerance range within 0 to 50 psu characterizes euryhaline amphyosmotic osmoregulators that originated from freshwater environments (Khlebovich \& Aladin 2010). Copepods from the Families Pseudodiaptomidae (C. aquaedulcis) and Diaptomidae (A. salinus) should be considered to be of marine origin and represent different stages of adaptation to freshwater environments (Grindley 1984).

Confusingly, Calanipeda aquaedulcis (the specific epithet means 'fresh water') withstood higher increases in salinity and acclimated more easily to higher salinities than Arctodiaptomus salinus (the specific epithet means 'salty'). Again, despite the fact that the majority of researchers rank $C$. aquaedulcis among marine species and $A$. salinus among freshwater species, we could not locate any literature record on findings of the former species in the open sea (only in estuarine areas), or on findings of the latter species in freshwater habitats, to support the above rankings. Moreover, both species can be found in nature within similar ranges of salinity, albeit in different habitats. Thus, the specific epithets that were derived from past descriptions of the copepod species without knowing the peculiarities of their ecological patterns can be rather confusing and may require adjustment (Boero 2011).

In this paper we have also demonstrated that the direct observations on changes in copepod body density following changes in water salinity allow us to resolve the question of whether a species is an osmoconformer or an osmoregulator. We have also demonstrated that it is possible to determine copepod body density by measuring the velocity of passive sinking of anesthetized animals. Such a methodological approach circumvents the effects derived from using a method that involves copepod volume-weight characteristics. In the supplement we present the equations and recalculate our previous data for the determination of body volumes and hydrodynamic characteristics of copepods required for the calculation of their body mass density. In order to apply these formulae to numerous copepod species without taking into consideration their species specifics, the formulae were unified to the basic copepod body proportions and space orientation during passive sinking.

Acknowledgements. This work was partially supported by the project PERSEUS (FP7-287600). We thank G. S. Minyuk and T. V. Rauen for help in the maintenance of the phytoplankton cultures used for feeding the copepods, and L. O. Aganesova for supplying the initial copepod cultures. We are grateful to the anonymous reviewers for their numerous helpful comments and suggestions.

\section{LITERATURE CITED}

Aladin NV, Plotnikov IS (2008) Modern fauna of residual water bodies formed on the place of the former Aral Sea. Proc Zool Inst Russ Acad Sci 312:145-154 (In Russian with an English abstract)

Aleyev YG, Khvorov SA (1985) Buoyancy as the function of live forms of hydrobionts. Hydrobiol J 21:24-28 (in Russian)

Alfonso G, Belmonte G (2011) Calanoida (Crustacea: Copepoda) from the inland waters of Apulia (south-eastern Italy). J Limnol 70:57-68

Anraku M (1964) Influence of the Cape Cod Canal on the hydrography and on the copepods in Buzzards Bay and Cape Cod Bay, Massachusetts. II. Respiration and feeding. Limnol Oceanogr 9:195-206

Battaglia B, Bryan GW (1964) Some aspects of ionic and osmotic regulation in Tisbe (Copepoda, Harpacticoida) in relation to polymorphism and geographical distribution. J Mar Biol Assoc UK 44:17-31

Beyrend-Dur G, Souissi S, Devreker D, Winkler G, Hwang JS (2009) Life cycle traits of two transatlantic populations of Eurytemora affinis (Copepoda: Calanoida): salinity effects. J Plankton Res 31:713-728

Boero F (2011) What is behind a species' name? Ital J Zool 78:409

- Brucet S, Boix D, López-Flores R, Badosa A, Quintana XD (2006) Size and species diversity of zooplankton communities in fluctuating Mediterranean salt marshes. Estuar Coast Shelf Sci 67:424-432

Calliari D, Andersen CM, Thor P, Gorokhova E, Tiselius P (2006) Salinity modulates the energy balance and reproductive success of co-occurring copepods Acartia tonsa and A. clausi in different ways. Mar Ecol Prog Ser 312: 177-188

Cervetto G, Gaudy R, Pagano M (1999) Influence of salinity on the distribution of Acartia tonsa (Copepoda, Calanoida). J Exp Mar Biol Ecol 239:33-45

Chen Q, Sheng J, Lin Q, Gao Y, Lv J (2006) Effect of salinity on reproduction and survival of the copepod Pseudodiaptomus annandalei Sewell, 1919. Aquaculture 258: $575-582$

> Chu D, Wiebe PH (2005) Measurements of sound-speed and density contrasts of zooplankton in Antarctic waters. ICES J Mar Sci 62:818-831

> Comin F, Alonso M (1988) Spanish salt lakes: their chemistry and biota. Hydrobiologia 158:237-245

> Devreker D, Souissi S, Molinero JC, Nkubito F (2008) Tradeoffs of the copepod Eurytemora affinis in mega-tidal estuaries: insights from high frequency sampling in the 
Seine estuary. J Plankton Res 30:1329-1342

Ermolaeva NI (2010) Characteristics of distribution of zooplankton in the lakes with different mineralization of Barabinsko-Kulundinskoi lake province (the south of Western Siberia). Ecology of aquatic invertebrates. Materials of the International Conference devoted to FD Mordukhai-Boltovskoi Centenary. Institute of Inland Water Biology of the Russian Academy of Sciences, Borok, p 90-92 (in Russian)

Finney CM (1979) Salinity stress in harpacticoid copepods. Estuaries 2:132-135

Ganning B (1971) Studies on the chemical, physical, and biological conditions in Swedish rockpool ecosystems. Ophelia 9:51-105

Garber BN (1951) Observation on development and reproduction of Calanipeda aquaedulcis Kritsch (Copepods, Calanoida). Proc Karadag Biol Stn 11:3-55 (in Russian)

Gnaiger E, Forstner H (eds) (1983) Polarographic oxygen sensors. Aquatic and physiological applications. Springer, Berlin

Goolish EM, Burton RS (1989) Energetics of osmoregulation in an intertidal copepod: effects of anoxia and lipid reserves on the pattern of free amino acid accumulation. Funct Ecol 3:81-89

Greenlaw CF (1977) Backscattering spectra of preserved zooplankton. J Acoust Soc Am 62:44-52

> Greenlaw CF, Johnson RK (1982) Physical and acoustical properties of zooplankton. J Acoust Soc Am 72:1706-1710

Grindley JR (1984) The zoogeography of the Pseudodiaptomidae. Crustac Suppl 7:217-228

Gross F, Raymont JEG (1942) The specific gravity of Calanus finmarchicus. Proc R Soc Edinb 61B:288-296

> Guerrero F, Jimenez-Melero R, Parra G, de la Torre MDL, Melguizo M (2007) Lipid composition of Arctodiaptomus salinus (Copepoda: Calanoida). J Freshw Ecol 22:147-150

Gyllenberg G, Lundqvist G (1978) Oxygen consumption of Eurytemora hirundoides nauplii and adults as a function of salinity. Ann Zool Fenn 15:328-330

Happel J, Brenner H (1965) Low Reynolds number hydrodynamics. Prentice-Hall, Englewood Cliffs, NJ

Hopper AF (1960) The resistance of marine zooplankton of the Caribbean and South Atlantic to changes in salinity. Limnol Oceanogr 5:43-47

Hubareva ES, Svetlichny LS, Kideys AE, Isinibilir M (2008) Fate of the Black Sea Acartia clausi and Acartia tonsa (Copepoda) penetrating into the Marmara Sea through the Bosphorus. Estuar Coast Shelf Sci 76:131-140

Ikeda T, Hirakava K, Kajihara N (1990) Some characteristics of a coldwater copepod Calanus cristatus from regions of the Japan Sea covered by Tsushima Warm Current. Bull Jpn Sea Natl Fish Res Inst 40:51-65

Ikeda T, Kanno Y, Ozaki K, Shinada A (2001) Metabolic rates of epipelagic marine copepods as a function of body mass and temperature. Mar Biol 139:587-596

> Ikeda T, Sano F, Yamaguchi A (2004) Metabolism and body composition of a copepod (Neocalanus cristatus: Crustacea) from the bathypelagic zone of the Oyashio region, western subarctic Pacific. Mar Biol 145:1181-1190

Ikeda T, Atsushi Y, Takashi M (2006) Chemical composition and energy content of deep-sea calanoid copepods in the Western North Pacific Ocean. Deep-Sea Res I 53: 791-1809

Ishikawa A, Sychei B, Shiga N (1999) Effects of salinity on survival, and embryonic and postembryonic development of Eurytemora affinis from a freshwater lake. Plankton
Biol Ecol 46:113-119

> Isla JA, Perissinotto R (2004) Effects of temperature, salinity and sex on the basal metabolic rate of the estuarine copepod Pseudodiaptomus hessei. J Plankton Res 26:579-583

> Jiménez-Melero R, Parra G, Souissi S, Guerrero F (2007) Post-embryonic developmental plasticity of Arctodiaptomus salinus (Copepoda: Calanoida) at different temperatures. J Plankton Res 29:553-567

Khlebovich VV (1981) Acclimation of animals. Nauka, Leningrad (in Russian)

Khlebovich VV, Aladin NV (2010) Salinity factor in animal life. Herald of the Russian Academy of Sciences 80: 299-304

> Knutsen T, Melle W, Calise L (2001) Determining the mass density of marine copepods and their eggs with a critical focus on some of the previously used methods. J Plankton Res 23:859-873

Køgeler JW, Falk-Petersen S, Kristensen A, Pettersen F, Dalen J (1987) Density- and sound speed contrast in sub-Arctic zooplankton. Polar Biol 7:231-235

Kovalev AV, Mazzocchi MG, Kideys AE, Skryabin VA (2006) Neritization of the plankton fauna in the Mediterranean basin. Mar Ecol J 1:5-15 (In Russian with an English abstract)

Lance J (1963) The salinity tolerance of some estuarine planktonic copepods. Limnol Oceanogr 8:440-449

- Lance J (1965) Respiration and osmotic behaviour of the copepod Acartia tonsa in diluted sea water. Comp Biochem Physiol 14:155-165

> Lee CE, Petersen CH (2003) Effects of developmental acclimation on adult salinity tolerance in the freshwaterinvading copepod Eurytemora affinis. Physiol Biochem Zool 76:296-301

Lee CE, Remfert JL, Chang YM (2007) Response to selection and evolvability of invasive populations. Genetica 129: 179-192

Lowndes AG (1942) The displacement method of weighing living aquatic organisms. J Mar Biol Assoc UK 25:555-574

Marrone F, Castelli G, Barone R, Naselli-Flores L (2006) Ecology and distribution of calanoid copepods in Sicilian inland waters (Italy). Verh Int Ver Limnol 29:2150-2156

Marshall SM, Orr AP (1972) The biology of a marine copepod. Springer-Verlag, New York, NY

Matsukura R, Yasuma H, Murase H, Yonezaki S, Funamoto T, Honda S, Miyashita K (2009) Measurements of density contrast and sound-speed contrast for target strength estimation of Neocalanus copepods (Neocalanus cristatus and Neocalanus plumchrus) in the North Pacific Ocean. Fish Sci 75:1377-1387

Mauchline J (1998) The biology of calanoid copepods. In: Blaxter JHS, Southward AJ, Tyler PA (eds) Advances in marine biology, Vol 33. Academic Press, San Diego, CA

> McAllen R, Taylor A (2001) The effect of salinity change on the oxygen consumption and swimming activity of the high-shore rockpool copepod Tigriopus brevicornis. J Exp Mar Biol Ecol 263:227-240

McAllen R, Taylor AC, Davenport J (1998) Osmotic and body density response in the harpacticoid copepod Tigriopus brevicornis in supralittoral rockpools. J Mar Biol Assoc UK 78:1143-1153

> Newrkla P (1978) The influence of ionic concentration on population parameters, development time, activity, and respiration rate of Arctodiaptomus spinosus (Daday) (Calanoida, Copepoda). Oecologia 33:87-99

Parra G, Jiménez-Melero R, Guerrero F (2005) Agricultural 
impacts on Mediterranean wetlands: the effect of pesticides on survival and hatching rates in copepods. Ann Limnol 41:161-167

Potts WTW (1954) The energetics of osmoregulation in brackish and freshwater animals. J Exp Biol 31:618-630

Ramdani M, Elkhiati N, Flower RJ, Birks HH, Kraïem MM, Fathi AA, Patrick ST (2001) Open water zooplankton communities in North African wetland lakes: the CASSARINA Project. Aquat Ecol 35:319-333

Ranta E (1982) Animal communities in rock pools. Ann Zool Fenn 19:337-347

Roddie BD, Leakey RJG, Berry AJ (1984) Salinity-temperature tolerance and osmoregulation in Eurytemora affinis (Poppe) (Copepoda: Calanoida) in relation to its distribution in the zooplankton of the upper reaches of the Forth estuary. J Exp Mar Biol Ecol 79:191-211

Rokneddine A, Chentoufi M (2004) Study of salinity and temperature tolerance limits regarding four crustacean species in a temporary salt water swamp (Lake Zima, Morocco). Anim Biol 54:237-253

Sartoris FJ, Thomas DN, Cornils A, Schnack-Schiela SB (2010) Buoyancy and diapause in Antarctic copepods: the role of ammonium accumulation. Limnol Oceanogr 55:1860-1864

Seuront L (2006) Effect of salinity on the swimming behaviour of the estuarine calanoid copepod Eurytemora affinis. J Plankton Res 28:805-813

Shadrin NV, Batogova EA, Kopeyka AV (2008) Arctodiaptomus salinus (Daday, 1885) (Copepoda, Diaptomidae), rare species in the northwestern Black Sea was found as a common one in the Crimea coastal zone. Mar Ecol J 7: 86 (in Russian)

Stepanov VN, Svetlichny LS (1981) The studies on hydromechanical characteristics of planktonic copepods. Naukova Dumka, Kiev (in Russian)

Svetlichny LS (1981) Body density of planktonic copepods. Ecology of marine organisms. Proceedings of the Union Scientific Technical Conference, Kiev, p 12-24 (in Russian)

Editorial responsibility: Anna Pasternak, Moscow, Russian Federation
Svetlichny LS (1983a) Calculation of the biomass of planktonic copepods using the coefficients of proportionality between volume and linear dimensions of the body. Ecol Morya 15:46-58 (In Russian with an English abstract)

Svetlichny LS (1983b) Hydrodynamic resistance of motionless copepods during their passive sinking in water. Oceanology 23:104-108

Svetlichny LS, Hubareva ES (2005) The energetics of Calanus euxinus: locomotion, filtration of food and specific dynamic action. J Plankton Res 27:671-682

Svetlichny LS, Hubareva ES, Arashkevich EG (1998) Physiological and behavioural response to hypoxia in active and diapausing copepodites Stage V Calanus euxinus. Arch Hydrobiol Spec Issues Advanc Limnol 52:507-519

> Svetlichny LS, Hubareva ES, Isinibilir M, Kideys AE, Belmonte G, Giangrande E (2010) Salinity tolerance of Calanus euxinus in the Black and Marmara Seas. Mar Ecol Prog Ser 404:127-138

Tang KW, Fenn TD, Visscher PT, Dam HG (2000) Regulation of body dimethylsulfoniopropionate (DMSP) content by the copepod Temora longicornis: a test of four mechanisms. Mar Biol 136:749-757

Tolomeev AP, Sushchik NN, Gulati RD, Makhutova ON, Kalacheva GS, Zotina TA (2010) Feeding spectra of Arctodiaptomus salinus (Calanoida, Copepoda) using fatty acid trophic markers in seston food in two salt lakes in South Siberia (Khakasia, Russia). Aquat Ecol 44: 513-530

Ventura M, Catalan J (2005) Reproduction as one of the main causes of temporal variability in the elemental composition of zooplankton. Limnol Oceanogr 50:2043-2056

> Visser AW, Jonasdottir SH (1999) Lipids, buoyancy and the seasonal vertical migration of Calanus finmarchicus. Fish Oceanogr 8:100-106

> Wang G, Jiang X, Wu L, Li S (2005) Differences in the density, sinking rate and biochemical composition of Centropages tenuiremis (Copepoda: Calanoida) subitaneous and diapause eggs. Mar Ecol Prog Ser 288:165-171

Submitted: December 14, 2011; Accepted: June 26, 2012 Proofs received from author(s): November 28, 2012 